\title{
A SYSTEMATIC QUANTITATIVE REVIEW OF VOLUNTEER MANAGEMENT IN EVENTS
}

\author{
EUNJUNG KIM AND GRAHAM CUSKELLY \\ Department of Tourism, Sport and Hotel Management, Griffith Business School, \\ Griffith University, Gold Coast Campus, Southport, Queensland, Australia
}

\begin{abstract}
Most event organizations rely on the commitment of volunteers to prepare for and stage events. An attempt to understand factors that affect volunteers' engagement and retention has received much attention from a substantial number of published studies. This article provides a systematic quantitative review of 71 original, peer-reviewed research articles published in English language academic journals on volunteer management in events. The review examines the nature of the research, methods, key concepts and theories, and types of research questions posed in studies associated with volunteer management in events. Published studies on event volunteer management are geographically concentrated in several countries but published in 35 different journals across a range of fields. Volunteer management in events has been the focus of rapidly increasing research attention in recent years with almost two thirds of the articles included in the review published in the 6 years leading to 2014. The majority of published research has not clearly articulated a theoretical framework and most studies have used survey methods to collect data from volunteers at mega-sport events. It was concluded that to advance knowledge of event volunteer management there is a need for increased collaboration internationally between researchers. Moreover, it is essential to engage with relevant theory in order to better understand and predict the effectiveness of volunteer management strategies in recruiting, retaining, and building a sense of community among volunteers in events.
\end{abstract}

Key words: Volunteer management; Human resource management (HRM); Volunteers; Events; Review

\section{Introduction}

Volunteer management in events has emerged as an increasingly important area of research endeavor and specialization that has drawn on a rich vein of volunteer management research from not-for-profit research (Allen \& Bartle, 2014; Farrell, Johnston, \& Twynam, 1998; Getz \& Frisby, 1988; Nichols \& Ojala, 2009; Wang \& Wu, 2014). Event volunteer management has developed as a subspecialization

Address correspondence to Eunjung Kim, Department of Tourism, Sport and Hotel Management, Griffith Business School, Business G 27_Room 2.08, Parklands Drive, Griffith University, Gold Coast Campus, Southport, Queensland 4222, Australia. Tel: +61 75552 7671; E-mail: eunjung.kim@griffithuni.edu.au 
of volunteer management because there are significant differences between the management of volunteers in event settings compared to mainstream volunteer management. Because the majority of events are at least fairly dependent on volunteer labor (Elstad, 2003), many event managers spend considerable resources on recruiting volunteers compared to other managers. For example, a survey in the UK assessed that $76 \%$ of the events sampled used volunteers (Rolfe, 1992; C. Ryan \& Bates, 1995). At events that are almost completely run by volunteers, it is important that the event develops over time a core group of volunteers that have capability in running events. According to Getz (1991), the management of volunteer efforts for events is significantly different from managing continuing or permanent volunteer positions. In particular, he suggests that the management of short-term events needs to focus more on resource acquirement (recruiting episodic volunteers) and creating community support (to encourage those within the community to volunteer).

To recruit and retain volunteers for short-term events, event organizations need to understand the tenets of volunteer management in event settings. However, despite an increasing research interest in event volunteers to date there have been no systematic reviews of volunteer management in events that describe the current state of research.
Therefore, the purpose of this review is to assess the nature and extent of peer-reviewed research literature on event volunteer management by an established systematic quantitative review technique. A greater understanding of event volunteer management is essential to develop a better understanding of recruitment practices and the commitment, satisfaction, and retention of volunteers in events (Allen \& Bartle, 2014; Allen \& Shaw, 2009; Bang, Alexandris, \& Ross, 2008; Bang \& Ross, 2009; Coyne \& Coyne Sr., 2001; Dickson, Benson, Blackman, \& Terwiel, 2013; Downward \& Ralston, 2005; Fairley, Kellett, \& Green, 2007; Giannoulakis, Wang, \& Gray, 2007; Hallmann \& Harms, 2012; Han, Quarterman, Strigas, \& Ha, 2013; Khoo \& Engelhorn, 2011; MacLean \& Hamm, 2007; Pauline \& Pauline, 2009; Skille \& Hanstad, 2013; Skirstad \& Hanstad, 2013; Twynam, Farrell, \& Johnston, 2002; Williams, Dossa, \& Tompkins, 1995; Wollebæk, Skirstad, \& Hanstad, 2014).

\section{Definition and Understanding of Key Terms}

The event volunteer management research literature reviewed in this article is defined by the intersection of events, volunteers, and human resource management (see Fig. 1), and each of these key concepts is further explored below.

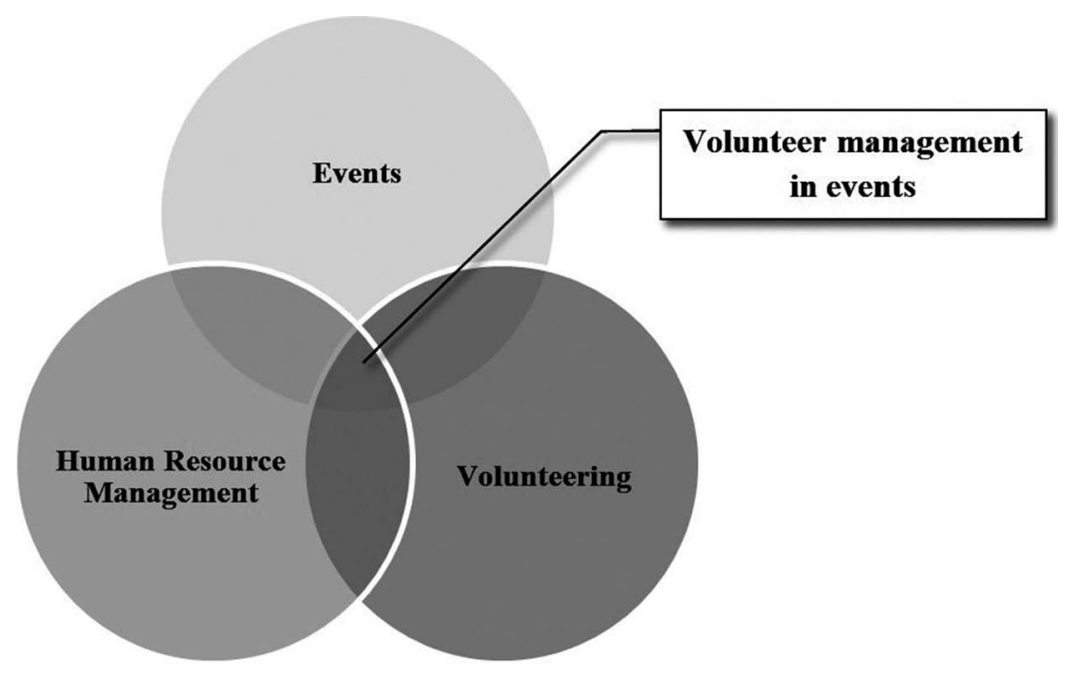

Figure 1. Conceptual framework explaining the domain of volunteer management in events. 


\section{Events}

Event studies is an emerging academic field (Skirstad \& Hanstad, 2013) that includes studies of a wide array of events, from local or regional events through to hallmark and mega-events, almost all of which involve volunteers. Mega-events have been described as "short-term events with long-term values” (Roche, 1994, p. 1). This description points to the economic as well as political, social, and cultural motives that encourage cities and countries to bid for the rights to host high profile events such as world championships and the Olympic Games. Roche (2000) further presented such happenings as "large-scale events which have a dramatic character, mass popular appeal and international significance” (p. 1), highlighting the role that events can have in destination development and image building. According to Getz (2008), events are an important motivator for the development and marketing plans of most destinations. Mega-events have been analyzed in terms of their tourist attractiveness or developmental roles. Also, Ritchie (1984) discussed a hallmark event as a major one-time or recurring event of limited duration, developed mainly to enhance the awareness, appeal, and effectiveness of a tourism destination. Similarly, local and regional events have potential benefits that can be developed in the local area such as the promotion of city brand or identity, attracting increased population, investment, or trade, and expansion of the visitor economy. This article takes an inclusive approach to identifying event studies literature. We acknowledge that the event studies literature includes studies of events that vary enormously in terms of size and scale. However, because there has not been a systematic review of the volunteer event management literature a restrictive approach to defining which types of events would be included in the review would have unnecessarily restricted its scope.

\section{Volunteering}

The International Labor Organization (ILO, 2011) defined volunteer work as "unpaid noncompulsory work; that is time individuals give without pay to activities performed either through an organization or directly for those outside their own household” (p. 13). Further, the ILO argued that volunteer work is most effective when properly managed. Based on the 37 countries studied, the Center for Civil Society Studies (2014) estimated that 140 million people engage in volunteering in a typical year and contribute US $\$ 400$ billion to the global economy. The Center for Civil Society Studies remarked that if the world's volunteers constituted a nation it would be the 8th largest country in the world and the 7th largest economy in Europe.

The contribution that volunteers make to the success of an event sees them recognized as an important part of the event labor force (Kemp, 2002). The Olympic Games commonly utilizes over 40,000 volunteers during any Games period (Cuskelly, Hoye, \& Auld, 2006) and the 2014 FIFA World Cup in Brazil was expected to use 80,000 volunteers (FIFA, 2012). Volunteering is beneficial to events because volunteers can enhance the event experience for participants. For example, an event can be enjoyable because of the enthusiasm, interest, and commitment of volunteers (Holmes \& Smith, 2009), and the range of skills, knowledge, and specific experience brought by volunteers can add value to a festival or event (Nichols \& Ojala, 2009). Event volunteering can contribute to local social and community involvement. For example, event volunteers from disadvantaged groups are often encouraged to develop their skills through involvement in event volunteering schemes (Allen, O’Toole, Harris, \& McDonnell, 2005; Carlsen \& Taylor, 2003). Understanding of volunteers' motivation and their expectations has been shown to be instrumental to achieve high levels of volunteer satisfaction (Barron \& Rihova, 2011).

In order to better understand volunteer motivations, expectations, and satisfaction it is essential to distinguish among the types of volunteers in events by how volunteers serve. A useful way to differentiate types of volunteers is to examine length of service. Common terms most used to describe length of service of a volunteer are long term, short term, and episodic (Connors, 2011). Long-term volunteers offer regularly occurring service to an organization for an extended period of time without a specified end date. Short-term volunteers provide regularly occurring service to an organization for a limited amount of time. This type of volunteer is identified as an "occasional episodic volunteer" or a volunteer who "provides service regularly for 
short periods of time" (Macduff, 1999, p. 188). Episodic volunteers provide infrequently occurring service to an organization, typically for a singleday or multiday event. Because episodic volunteers participate in volunteering during a short period, supervision of episodic volunteers tends be different from that associated with continuous/long-term volunteers (Macduff, 1999). To attract episodic volunteers, event volunteer managers may need to use human resource management processes such as recruitment, screening, supervision, training, recognition, and evaluation that are different to processes used to manage volunteers involved in longer-term or continuous assignments (Macduff, 1999). The present study is focused on episodic volunteer management in events.

\section{Human Resource Management}

Human resource management (HRM) involves specific practices such as recruitment, selection, appraisal, rewards, measurement, training and development, communications, and work design (Beatty, Huselid, \& Schneier, 2003). Although HRM practices are widely variable (Keenoy, 1999), HRM is essentially how to recruit, develop, and motivate people (Cuskelly, Taylor, Hoye, \& Darcy, 2006).

However, managing event volunteers is fundamentally different to managing volunteers in organization settings (Australian Sports Commission, 2000). Events deal with a different set of volunteer management challenges because of their temporary or irregular nature, compared to managing long-term volunteers. The difference is due to the short-term nature of the commitment of event volunteers (Australian Sports Commission, 2000). As such, few event organizations have a formal system of HRM and many do very little planning or tend to depend on informal systems (Australian Sports Commission, 2000). In the context of event volunteer management, HRM is concerned with the demand and supply of volunteer labor. The purpose of HRM is to ensure that "a predetermined number of employees with the correct skills are available at a specified time in the future" (Deb, 2009, p. 178). The benefits of HRM include more effective and efficient use of volunteers in specific positions, and better performing and potentially more satisfied event volunteers. In addition, given the short-term involvement of event volunteers HRM allows the event organizations to better prepare for the particular needs of volunteers. Therefore, there have been consistent calls for researchers to understand the HRM practices in the field of volunteer resource management (Safrit, Schmiesing, Gliem, \& Gliem, 2005). Volunteer management in events has examined various aspects affecting commitment, retention, and recruitment, but a comprehensive assessment of research on this topic is lacking.

\section{Research Objectives and Methods}

A systematic quantitative literature review was implemented using a methodology that has been used in various reviews (Petticrew, 2001). It uses an explicit and reproducible approach to arrange the literature in relation to subject, location, and research technique (Pickering, Grignon, Steven, Guitart, \& Byrne, 2014). Articles are searched and categorized through a structured search process using relevant keywords to identify the existing literature (Pickering \& Byrne, 2014). The identified literature is then examined against a series of inclusion standards leading to a collection of articles that represent a research topic (Pickering et al., 2014). Articles are then quantified to provide the "scope, depth, and breadth of research" (Pickering \& Byrne, 2014, p. 6) on the topic in question and the reproducible, reliable assessments of the current status of a field of research (Roy, Pickering, \& Byrne, 2012). The results of quantitative assessment are the geographical spread of the literature, the spread of the literature by year, the types of questions researched, the methods used, and the types of research results obtained.

The article reviews the research literature on volunteer management in events and explores the following questions: (1) Who has conducted the research? (2) Where and when was it published? (3) What was the geographical location of events studied and the affiliation of the authors? (4) What methods were used? (5) What key concepts, constructs, and theories underpinned the research? (6) What types of research questions were examined?

Original, peer-reviewed research articles published in English language scholarly journals on the topic of volunteer management in events were 
included in the review. Peer-reviewed research articles were identified and retrieved through a keyword search of electronic databases that extended to Google Scholar, ProQuest, Scopus, Science Direct, Sage, as well as the authors' university library between May and December 2014. Year of publication was not restricted. Key words used for the searches were "volunteer and management" and a combination of the following terms; "event," "sport," "motivation,” “commitment," “intention,” “retention,” “participation,” "volunteer,” “"organization,” "recruitment," "volunteering,” and “engagement.” However, peer-reviewed research articles with words such as "non-profit organization not in events” (e.g., Red Cross, social services, training and education, disaster and humanitarian aid) were excluded. Also excluded were articles that focused on sport volunteers where the research setting was not events (e.g., sport clubs, sport for development, sport leadership, and coaching). Research reports, conference proceedings, books, and book chapters were also excluded from the review. Many peerreviewed research articles were cited in subsequently published research articles. Therefore, the reference lists of published peer-reviewed research articles were also checked to ensure that a comprehensive list of event volunteer management peerreviewed research publications was constructed.

Information from each peer-reviewed research article examining volunteer management in events was identified, retrieved, recorded, and coded in a Microsoft Excel spreadsheet. The coded information included: author, author country affiliation, journal title, year of publication, field, country where research was conducted, methods used in the research (e.g., data collection methods, type of data, type of sample, organizational perspective or individual perspective or both), key concepts, constructs, and theories, as well as research questions. Discussions between the two authors were used to develop coding categories and to ensure validity and consistency in the classification process.

The reported data collection methods in each of the research articles were coded and classified as survey, interview, focus group, participant observation, observation, and analysis of preexisting (secondary) data. The source of data (e.g., participants, interviewee, organizer), the number and types of samples involved in each article, and the number of perspectives (e.g., organizational, individual or both) in each article were coded and recorded. The type of data collected was classified as quantitative, qualitative, or both. Key concepts and constructs (e.g., motivation, human resource management processes) and theories (e.g., theory of planned behavior, self-determination theory, social exchange theory) were also coded and recorded. Finally, the research questions by variables and concepts affecting event volunteer management were classified under types of research questions (e.g., cause and effect, relationship between variables, difference between groups, and prediction).

We did not give a weight to specific studies as research has been conducted across diverse fields. The database of research articles was analyzed to identify categories, patterns, and trends in the event volunteer management research literature.

\section{Results}

After deletion of duplicates, a total of 71 peerreviewed research articles on volunteer management in events published between 1988 and 2014 were included in the systematic review. Analysis of the reviewed articles is reported in terms of: (1) the scope of the research (world region, year published, and field of publication); (2) research methods used; (3) theoretical basis of the research; (4) conceptualization and measurement of main constructs; and (5) types of research questions.

\section{Scope of the Research}

The research was conducted by 157 authors across 14 different countries. Most articles were from data collected at events in the US (17.8\%), Canada (15.1\%), Australia (15.1 \%), UK (12.3\%), and Norway (9.6 \%) (see Table 1). In total, 60\% of the events researched were hosted in the US, Canada, Australia, and the UK. There were comparatively few peer-reviewed research papers that collected data from Greece (5.5 \%), Korea (5.5\%), China (5.5\%), Switzerland (2.7\%), and New Zealand (2.7\%). Iran, Germany, Egypt, and South Africa were the subject of event volunteer management in four one-off peer-reviewed articles. Of the 157 authors of event volunteer management 
Table 1

Distribution of Peer-Reviewed Research Articles Examining Volunteer Management in Events by Study Location and Country of Author (Based on Author Affiliation)

\begin{tabular}{lcc}
\hline Country & $\begin{array}{c}\text { Study Locations } \\
\text { [Frequency (\%)] }\end{array}$ & $\begin{array}{c}\text { Authors } \\
\text { [Frequency (\%) }]^{\mathrm{a}}\end{array}$ \\
\hline United States & $13(17.8)$ & $31(19.7)$ \\
Canada & $11(15.1)$ & $25(15.9)$ \\
Australia & $11(15.1)$ & $23(14.6)$ \\
United Kingdom & $9(12.3)$ & $27(17.1)$ \\
Norway & $7(9.6)$ & $12(7.6)$ \\
Greece & $4(5.5)$ & $8(5.1)$ \\
Korea & $4(5.5)$ & $6(3.8)$ \\
China & $4(5.5)$ & $3(1.9)$ \\
Switzerland & $2(2.7)$ & $6(3.8)$ \\
New Zealand & $2(2.7)$ & $5(3.2)$ \\
Iran & $1(1.4)$ & $3(1.9)$ \\
Germany & $1(1.4)$ & $2(1.3)$ \\
Egypt & $1(1.4)$ & $2(1.3)$ \\
South Africa & $1(1.4)$ & $1(0.6)$ \\
Kuwait & - & $1(0.6)$ \\
Malaysia & - & $1(0.6)$ \\
Taiwan & - & $1(0.6)$ \\
Not specified & $2(2.7)$ & - \\
Total & $73^{\mathrm{b}}$ & 157 \\
\hline
\end{tabular}

${ }^{\mathrm{a}}$ Does not add to $100 \%$ due to rounding.

${ }^{\mathrm{b}}$ Total $>71$. One article by Dickson, Benson, and Terwiel (2014) and one article by Kemp (2002) examined volunteer management in events in two different countries.

peer-reviewed research articles, at the time of their publication, $19.7 \%$ were affiliated with institutions in the US. In total, $67 \%$ of author affiliations were with the US, Canada, Australia, and the UK. Other authors' affiliations at the time of publication were UK (17.1 \%), Canada (15.9\%), Australia (14.6\%), Norway (7.6 \%), Greece (5.1\%), Korea (3.8\%), Switzerland (3.8\%), and New Zealand (3.2\%). There were three authors each with affiliations with China and Iran, two authors each from Germany and Egypt, and one each from South Africa, Kuwait, Malaysia, and Taiwan.

The 71 research articles included in the systematic review are represented in a cumulative frequency distribution chart (see Fig. 2). The mean number of articles published annually during the 27-year period of this review is 2.63. The first published article was authored by Getz and Frisby (1988) and evaluated management effectiveness in community run festivals. There was a 7-year gap until the next published event volunteer management article by Williams et al. (1995). To identify trends in the volume of research publications the period covered by this review (1988 to 2014) was divided into four approximately equal time periods (three of 7 years and one of 6 years). There was a significant acceleration in event volunteer management research publications from the first period (1988 to 1994) with one publication to the second publication period (1995 to 2001) during which seven research articles were published. The number of articles more than doubled to 18 research articles in the third 7-year period (2002 to 2008). From 2009, the number of published research articles more than doubled again to a total of 45 articles published over a 6-year period (2009 to 2014). The field of event volunteer management research developed slowly in the first 14 years but accelerated rapidly in the fourth time period (2009 to 2014). As a proportion of the total research articles reviewed, $11.3 \%$ were published between 1988 and 2001 compared to 88.7\% published from 2002 to 2014. Almost two thirds of the event volunteer management research articles reviewed (63.3\%) were published in the 6 years from 2009 to 2014 .

Reflecting the various interests in volunteer management in events, research articles were published in 35 different journals across a wide range of fields (see Table 2). These included journals in event (30.9\%), sport (22.5\%), leisure (18.3\%), nonprofit and volunteering (7.0\%), and tourism (5.6 \%). Other fields were represented but their comparative contributions have been less prevalent. The journals that have published the largest proportion of event volunteer management research articles were Event Management (18.3 \%), Managing Leisure (9.8\%), Sport Management Review (7.0 \%), and Leisure/Loisir (7.0\%).

\section{Research Methods and Sampling}

A range of methods have been used to research volunteer management in events (see Table 3). A total of 91 methods were identified in the 71 published articles, with a number of articles using more than one method. Most researchers used a quantitative $(71.8 \%)$ rather than a qualitative approach (18.3\%). Seven of the 71 published articles (less than $10 \%$ ) used a mixed-methods approach. The most widely reported method was by survey (69.2\%), which included online, onsite, and postal. 


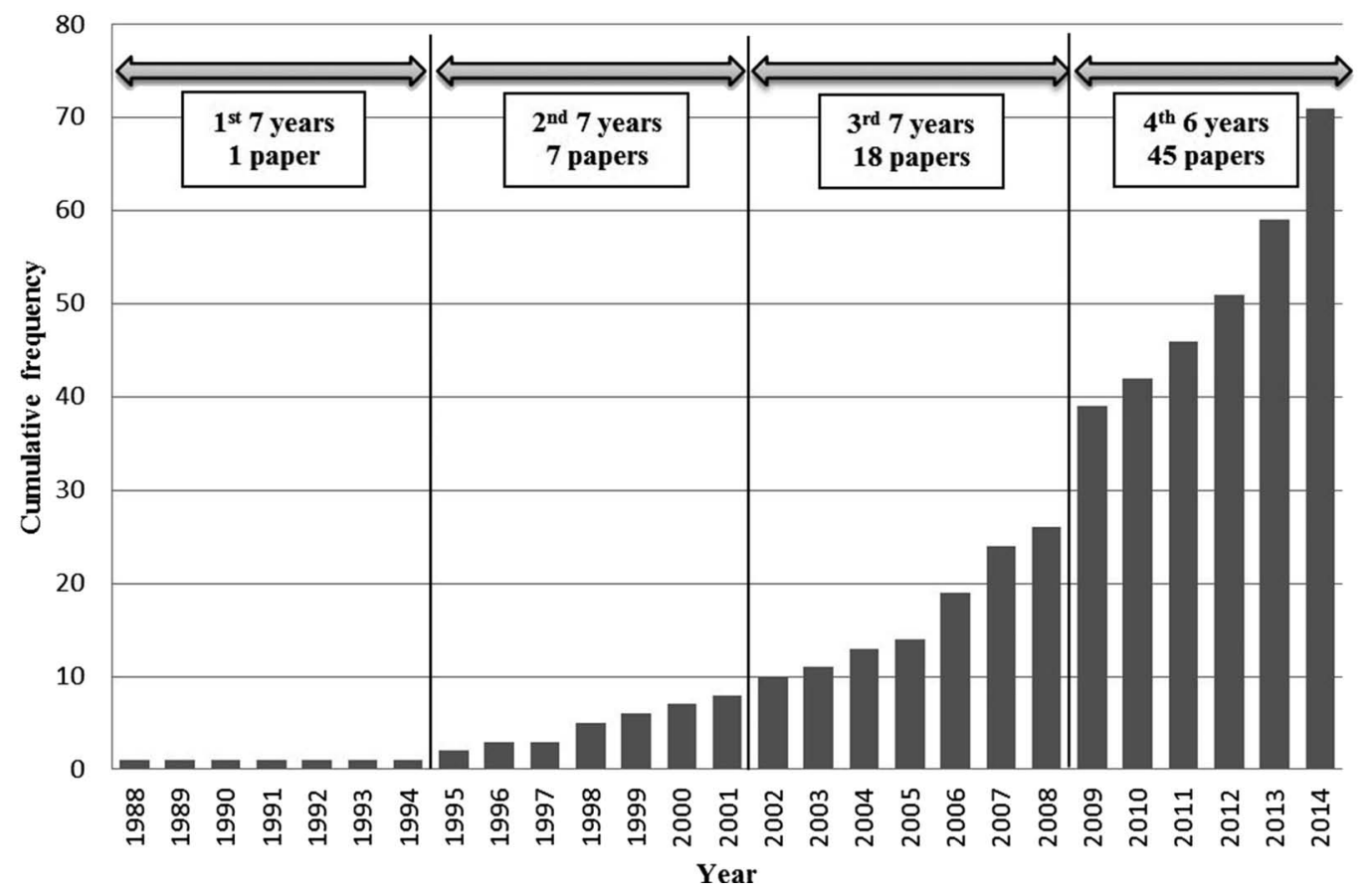

Figure 2. Cumulative frequency of journal articles examining volunteer management in events by year published.

Other methods were interview (15.3\%), focus group (6.5\%), participant observation (3.2 \%), and observation (2.1\%). Three articles analyzed preexisting (secondary) data. A large proportion of data collection occurred around the staging of a targeted event $(n=56)$. The most frequently researched events were sport events $(n=48)$, many of which were classified as mega-events $(n=42)$. Fourteen event organizations involving volunteers were sampled and students from three universities were also sampled. Because eight articles did not provide sufficient details to decipher their sampling, the total number of samples is not reported.

Perspective takes into account that different levels of analysis exist (Wicker \& Hallmann, 2013). For example, individuals are nested within organizations-school children within schools, players within teams (Todd, Crook, \& Barilla, 2005). Studies in the field of volunteer management in events see event volunteers nested within event organizations. Because different perspectives can lead to different findings (Bolman \& Deal, 1991), articles examined the individual perspective, organizational perspective, or both to assess whether differences existed between the perceptions of volunteers and management practices of the organization. Most articles collected data from an individual volunteer perspective $(84.5 \%)$. Data were mainly sourced from volunteers through surveys and interviews, although there was one article that included data from organizers. Ten articles focused on both individual and organizational perspectives (see Table 3).

\section{Theoretical Base}

Where possible the theories underpinning each of the reviewed research articles were identified and coded. In this section, we used the terms "cited" and "applied." Cited means that a study mentioned a theoretical framework but there was no evidence that the research tested the cited theory. Applied means that a study was based on a specifically identified theory that informed the direction and research design of the article as well as being evident in the results and discussion.

Theories related to volunteer management in events were cited 36 times in 28 research articles 
Table 2

Field and Journal Distribution of the 71 Research Papers on Volunteer Management in Events Reviewed in This Study

\begin{tabular}{|c|c|c|}
\hline Field/Journal Titles & Journal Frequency & Field Frequency (\%) \\
\hline Event (6) & & $22(30.9)$ \\
\hline Event Management & 13 & \\
\hline Festival Management \& Event Tourism & 3 & \\
\hline International Journal of Event and Festival Management & 3 & \\
\hline Journal of Convention \& Event Tourism & 1 & \\
\hline International Journal of Event Management Research & 1 & \\
\hline Journal of Venue and Event Management & 1 & \\
\hline Sport (7) & & $16(22.5)$ \\
\hline Sport Management Review & 5 & \\
\hline European Sport Management Quarterly & 3 & \\
\hline Journal of Sport Management & 3 & \\
\hline Sport in Society & 2 & \\
\hline International Journal of Sport Management and Marketing & 1 & \\
\hline International Journal of Sport Management & 1 & \\
\hline The International Journal of Sport and Society & 1 & \\
\hline Leisure (3) & & $13(18.3)$ \\
\hline Managing Leisure & 7 & \\
\hline Leisure/Loisir & 5 & \\
\hline Society and Leisure & 1 & \\
\hline Nonprofit and Volunteering (4) & & $5(7.0)$ \\
\hline Voluntas: International Journal of Voluntary and Nonprofit Organizations & 2 & \\
\hline Australian journal on volunteering & 1 & \\
\hline International Review on Public and Nonprofit Marketing & 1 & \\
\hline Nonprofit and Voluntary Sector Quarterly & 1 & \\
\hline Tourism (4) & & $4(5.6)$ \\
\hline Journal of Travel Research & 1 & \\
\hline Asia Pacific Journal of Tourism Research & 1 & \\
\hline Tourismos: An international multidisciplinary journal of tourism & 1 & \\
\hline Tourism and Hospitality Planning \& Development & 1 & \\
\hline Sociology (2) & & $2(2.8)$ \\
\hline International Review for the Sociology of Sport & 1 & \\
\hline World Journal of Social Sciences & 1 & \\
\hline Hospitality (1) & & $1(1.4)$ \\
\hline International Journal of Hospitality Management & 1 & \\
\hline Human Resource (1) & & $1(1.4)$ \\
\hline Human Resource Development International & 1 & \\
\hline Other (7) & & $7(9.8)$ \\
\hline Journal of European Industrial Training & 1 & \\
\hline WASET International Science Index & 1 & \\
\hline Urban Studies & 1 & \\
\hline Team Performance Management & 1 & \\
\hline $\begin{array}{l}\text { ICHPER--SD Journal of Research in Health, Physical Education, } \\
\text { Recreation, Sport \& Dance }\end{array}$ & 1 & \\
\hline Journal of Policy Research in Tourism, Leisure and Events & 1 & \\
\hline Adapted Physical Activity Quarterly & 1 & \\
\hline Total & 71 & 71 \\
\hline
\end{tabular}

${ }^{\mathrm{a}}$ Does not add to $100 \%$ due to rounding.

and applied 15 times in 9 research articles. Several articles discussed more than one theory (see Table 4). More than half of the research articles reviewed (60.5\%) neither cited nor applied an identifiable theory. The theories of planned behavior and reasoned action (Ajzen, 1988; Fishbein \&
Ajzen, 1975) were the most frequently referred to, and were either cited or applied in six articles. Self-determination theory (R. M. Ryan \& Deci, 2000) was cited in five articles, with only one study applying the theory. Four research articles cited social exchange theory (Blau, 1964; Homans, 
Table 3

Research Methods Used, Samples, and Perspectives in the 71

Research Articles on Volunteer Management in Events Examined in This Study

\begin{tabular}{lc}
\hline Category & Frequency \\
\hline Methods used & \\
Detail of the methods & $91^{\mathrm{a}}$ \\
Online survey & 21 \\
Onsite survey & 20 \\
Interview & 14 \\
Survey by postal mail & 12 \\
Survey (method not specified) & 10 \\
Focus group & 6 \\
Participant observation & 3 \\
Observation & 2 \\
Other (analysis of preexisting/secondary data) & 3 \\
Type of data & 71 \\
Quantitative & 51 \\
Qualitative & 13 \\
Both (mixed methods) & 7 \\
Samples & \\
Type of events & \\
Sport events & $56^{\mathrm{e}}$ \\
Cultural events & 48 \\
Business events & 5 \\
Scale of events & \\
Mega-events & 3 \\
Hallmark events & $56^{\mathrm{e}}$ \\
Local events & 42 \\
Event organization & 12 \\
University & 2 \\
Not specified & 14 \\
Perspectives & 3 \\
Individual & $8^{\mathrm{f}}$ \\
Organizational & 71 \\
Both & 60 \\
\hline
\end{tabular}

Total $>71$. Several articles used more than one method.

bome articles reported more than one sample.

'Category used in Bowdin, Allen, O’Toole, Harris, and McDonnel (2006).

${ }^{\mathrm{d} C}$ Category used in Getz (2005).

${ }^{\mathrm{e}}$ Events categorized by both type and scale of events.

${ }^{\mathrm{f}}$ The number of articles that did not provide sufficient details to decipher sampling.

1958; Thibault \& Kelly, 1959). Psychological contract theory (Rousseau, 1989) and motivation theory (Herzberg, 1986; Maslow, 1987) were each cited in three articles but not clearly applied. Flexibility theory (Atkinson, 1984) was cited in one article and applied in another. A number of theories were either cited or applied in only one of the research articles reviewed. These included reflexive modernization theory (Beck, 1992), theory of social capital (Coleman, 1988; Portes, 1998), theory of human capital (Becker, 1964), theory of political capital (Bourdieu, 1991), theory of work adjustment (Dawis \& Lofquist, 1984), expectation theory (Becker, 1976), identity theory (Callero, Howard, \& Piliavin, 1987), associative-supportivecognizant theory (Clary, Snyder, Ridge, Miene, \& Haugen, 1994; Houle, Sagarin, \& Kaplan, 2005; Peterson, 2004), critical theory (Alvesson \& Willmott, 1992; Grey \& Willmott, 2005), functional theory (Clary et al., 1998; Katz, 1960), self-regulation theory (Bandura, 1991), theory of habitus (Bourdieu, 1977), and theory of sport fan involvement (Lavarie \& Arnett, 2000; Shank \& Beasley, 1998; Wann, Melnick, Russell, \& Pease, 2001). 
Table 4

Theories Used in the 71 Research Articles on Volunteer Management in Events Examined in This Study

\begin{tabular}{lcc}
\hline Theories & Cited $^{\mathrm{a}}$ & Applied $^{\mathrm{b}}$ \\
\hline Theory of planned behavior or Theory of reasoned action (Ajzen, 1988; Fishbein \& Ajzen, 1975) & 6 \\
Self-determination theory (Ryan \& Deci, 2000) & 5 & 6 \\
Social exchange theory (Blau, 1964; Homans, 1958; Thibault \& Kelly, 1959) & 4 & - \\
Psychological contract theory (Rousseau, 1989) & 3 \\
Motivation theory (Herzberg, 1968; Maslow, 1987) & 3 \\
Flexibility theory (Atkinson, 1984) & 1 \\
Reflexive modernization theory (Beck, 1992) & 1 \\
Theory of social capital (Coleman, 1988; Portes, 1998) & 1 \\
Theory of human capital (Becker, 1964) & 1 \\
Theory of political capital (Bourdieu, 1991) & 1 \\
Theory of work adjustment (Dawis \& Lofquist, 1984) & 1 \\
Expectation theory (Becker, 1976) & 1 \\
Identity theory (Callero et al., 1987) & 1 \\
Associative-supportive-cognizant theory (Clary et al., 1994; Houle et al., 2005; Peterson, 2004) & 1 \\
Critical theory (Alvesson \& Willmott, 1992; Grey \& Willmott, 2005) & 1 \\
Functional theory (Clary et al., 1998; Katz, 1960) & 1 \\
Self-regulation theory (Bandura, 1991) & - \\
Theory of habitus (Bourdieu, 1977) & - \\
Theory of sport fan involvement (Lavarie \& Arnett, 2000; Shank \& Beasley, 1998; Wann et al., 2001) & 1 \\
Total & 1 \\
\hline
\end{tabular}

${ }^{\mathrm{a}}$ Cited, discussed and mentioned but not evidently assessed in the paper.

${ }^{\mathrm{b}}$ Applied, demonstrated and explicitly researched through methods in the paper. Applied is a sub-group of Cited.

${ }^{\mathrm{c}}$ Total $<71$. A total of 43 papers neither cited nor applied specified theories.

\section{Conceptualization and Measurement}

The concepts and constructs used in each of the research articles were identified and coded. It is acknowledged that concepts and constructs are not identical in that concepts are a generalized notion or idea about a class of objects and constructs turn concepts into systematically organized ideas (Neuman, 2011), often for the purposes of measurement. However, in this review the terms concepts and constructs were used interchangeably and are referred to as concepts.

A total of 16 concepts were identified and coded 142 times across the 71 research articles reviewed. Many of the research articles studied more than one concept related to volunteer management in events (see Table 5). These included, in frequency order, motivation, retention, satisfaction, recruitment, commitment, experience, volunteer legacy, identity, expectation, flexibility, media, job performance, career volunteering, volunteer learning, and motivational climate.

The concept of motivation was evident in more than a quarter of the articles reviewed and accounted for $28.9 \%$ of the total number of concepts researched.
Table 5

Key Concepts and Constructs Used in the 71 Research Articles on Volunteer Management in Events Examined in This Study

\begin{tabular}{lc}
\hline Key Concepts and Constructs & Frequency (\%) \\
\hline Motivation & $41(28.9)$ \\
Retention (intention to continue) & $30(21.1)$ \\
Satisfaction & $18(12.7)$ \\
Recruitment & $12(8.5)$ \\
Commitment (engagement) & $10(7.0)$ \\
Experience & $7(4.9)$ \\
Motivation measurement & $5(3.5)$ \\
Volunteer legacy & $4(2.8)$ \\
Identity & $3(2.1)$ \\
Expectation & $3(2.1)$ \\
Flexibility & $2(1.4)$ \\
Media & $2(1.4)$ \\
Job performance & $2(1.4)$ \\
Career volunteering & $1(0.7)$ \\
Volunteer learning & $1(0.7)$ \\
Motivational climate & $1(0.7)$ \\
Total & $142^{\mathrm{b}}$ \\
\hline
\end{tabular}

${ }^{a}$ Does not add to $100 \%$ due to rounding.

${ }^{\mathrm{b}}$ Total $>71$. More than one concept or construct examined in most articles. 
Some articles adapted existing measurement scales or developed new scales to measure event volunteer motivation. These measurement scales included: Special Event Volunteer Motivation Scale (SEVMS) (six articles); Volunteer Motivation Scale for International Sporting Events (VMS-ISE) (five articles); Volunteer Functions Inventory (VFI) (one articles); Associative-supportive motivation (one article); and Olympic Volunteer Motivation Scale (OVMS) (one article). The next most frequently measured concepts were volunteer retention (21.1\%) coded to include future voluntary engagement, intentions to continue, and to remain as a volunteer for future events and volunteer satisfaction (12.7\%). Together motivation, retention, and satisfaction accounted for $62.7 \%$ of the concepts researched across the 71 reviewed articles. A total of 12 articles (8.5 \%) measured recruitment in examining volunteer selection and seeking pathways for continuous improvement in the process of recruitment. Commitment was categorized with engagement and was investigated in 10 articles (7.0\%) to examine the relationships between motivation and commitment, factors influencing the commitment of volunteers, and to enhance volunteer commitment. Experience, as a broad concept, was identified in seven articles and included sport event volunteer experience, experience of training and associated learning, and generated a greater understanding of sport event volunteerism by personal lived experience. Less than five articles researched concepts that included volunteer legacy, identity, expectation, flexibility, media, career volunteers, volunteer learning, and motivational climate.

\section{Types of Research Questions}

Of the 71 articles reviewed a total of 78 research questions were identified as several articles studied more than one research question (see Table 6). A total of 24 research questions examined "cause and effect" relationships between independent and dependent variables with 20 positive results, one negative result, and three mixed results in terms of volunteer management processes, volunteer satisfaction, or the experiences of volunteers. A total of 22 research questions focused on relationships between variables and 12 research questions examined differences between groups regarding motivation. Finally, 20 research questions were focused on prediction in order to better understand effective volunteer management in events.

Not surprisingly, motivation was the mostly frequently used term in the research questions. Motivation was used predominantly as an independent variable to research volunteer attitudes or behaviors, and appeared in 40 of 71 research articles reviewed. Differences in motivations between groups of volunteers $(n=12)$ was a frequently asked research question. Other studies examined satisfaction, commitment, retention, and recruitment as the key term in the research questions (see Table 6).

In summary, peer-reviewed research articles on the topic of event volunteer management have been concentrated within certain countries but published in 35 different journal titles across a range of fields. Volunteer management in events has been the focus of increased research attention over the past 6 years with almost two thirds of the 71 articles included in this review being published between 2009 and 2014. Most research articles have taken a quantitative approach to data collection using survey methods and have sampled mega-sport event volunteers. The theories of planned behavior and reasoned action (Ajzen, 1988; Fishbein \& Ajzen, 1975) were the most frequently cited theories. However, more than half of the research articles reviewed neither cited nor applied an identifiable theoretical base. Key concepts and main research questions were mostly concerned with volunteer motivation, retention, and satisfaction.

\section{Discussion}

The purpose of this review of the event volunteer management literature was to uncover patterns and trends in the development and focus of this increasingly important and rapidly developing field of research. An established systematic quantitative literature review method was used to identify code and analyze the peer-reviewed literature on event volunteer management. The approach taken was to identify the scope, methods, theories, concepts, and types of research questions from the first identifiable event volunteer management article published in 1988 until the end of 2014. Such an approach enabled important trends as well as possible gaps in the literature to be identified, which in turn may assist in developing an agenda for future research 
Table 6

Types of Research Questions Reported in the 71 Research Articles on Volunteer Management in Events Examined in This Study

\begin{tabular}{|c|c|}
\hline Types of Research Questions & Frequency \\
\hline Cause and effect & 24 \\
\hline Positive & 20 \\
\hline Motivation $\rightarrow$ commitment & 4 \\
\hline Experience $\rightarrow$ commitment & 1 \\
\hline Motivation $\rightarrow$ satisfaction & 4 \\
\hline Learning experience $\rightarrow$ satisfaction & 1 \\
\hline Identity $\rightarrow$ satisfaction & 1 \\
\hline Motivation $\rightarrow$ retention & 4 \\
\hline Job design $\rightarrow$ retention & 1 \\
\hline Social, Human, Political capital $\rightarrow$ recruitment & 1 \\
\hline Motivation $\rightarrow$ recruitment & 1 \\
\hline Public service advertisement $\rightarrow$ recruitment & 1 \\
\hline Satisfaction $\rightarrow$ recruitment & 1 \\
\hline Negative & 1 \\
\hline Volunteer learning $\rightarrow$ experience & 1 \\
\hline Mixed & 3 \\
\hline Media $\rightarrow$ commitment & 2 \\
\hline Flexibility $\rightarrow$ satisfaction and retention & 1 \\
\hline Relationship between variables & 22 \\
\hline Motivation-commitment & 6 \\
\hline Satisfaction-commitment & 2 \\
\hline Career volunteers-commitment & 1 \\
\hline Motivation-recruitment & 4 \\
\hline Motivation-retention & 2 \\
\hline Psychological contract-retention & 1 \\
\hline Identity-retention & 1 \\
\hline Satisfaction-retention & 1 \\
\hline Motivation-motivational climate & 1 \\
\hline Motivation-satisfaction & 2 \\
\hline Experience-satisfaction & 1 \\
\hline Difference between groups & 12 \\
\hline Motivation & 12 \\
\hline Prediction & 20 \\
\hline TPB or TRA ${ }^{\mathrm{a}} \rightarrow$ retention & 3 \\
\hline Motivation and satisfaction $\rightarrow$ retention & 3 \\
\hline Identity $\rightarrow$ retention & 1 \\
\hline Volunteer legacy $\rightarrow$ retention & 1 \\
\hline Satisfaction $\rightarrow$ commitment & 3 \\
\hline Experience $\rightarrow$ recognition & 2 \\
\hline Volunteer legacy $\rightarrow$ recognition & 1 \\
\hline Expectation $\rightarrow$ recruitment & 1 \\
\hline Motivation and expectation $\rightarrow$ recruitment & 1 \\
\hline Mentoring $\rightarrow$ recruitment & 1 \\
\hline Flexibility $\rightarrow$ recruitment and retention & 1 \\
\hline Psychological contract $\rightarrow$ expectation and recognition & 1 \\
\hline Systematic framework $\rightarrow$ effectiveness & 1 \\
\hline Total & $78^{\mathrm{b}}$ \\
\hline
\end{tabular}

${ }^{\mathrm{a}} \mathrm{TPB}$, Theory of planned behavior; TRA, Theory of reasoned action. ${ }^{b}$ Total $>71$. Several articles studied more than one main research question. 
in this rapidly evolving field. Several key findings have emerged from the review: (1) the research is concentrated in four countries; (2) research interest has accelerated rapidly over the last decade; (3) much of the published research does not have a clearly articulated theoretical basis; (4) quantitative research methods have been the most common; and (5) volunteer motivation is the most frequently researched topic.

\section{Geographically Concentrated Research}

The review identified and retrieved 71 peerreviewed research articles on volunteer management in events that were published in 35 different English language journals. However, whether by the event researched or by authors' institutional affiliation the majority of published research is dominated by the US, Canada, Australia, and the UK. Two thirds of the authors were affiliated with one of the four dominant countries and of the events studied $60 \%$ were from these same countries. There was limited evidence of published research originating from other world regions or countries. Significant regions appear to have little or no research published on this topic even though they host and stage events and presumably rely on volunteers to assist with the staging of events (e.g., South America, India, and the subcontinent, Russia and China). There are three possible reasons. First, the review was limited to English language journals. Reviewing non-English language peer-reviewed journals would capture a broader array of events and volunteers assuming research of this nature is being undertaken and published. However, including research articles in languages other than English would present a major challenge but could identify significantly different patterns and trends in event volunteer management research than the results reported here as well as highlighting the impact of cultural differences in event volunteer management. Second, it is likely that there is a tendency for major sport events to be hosted more frequently in the countries that have dominated the research literature on this topic compared to other countries. Although there is evidence of mega-sport events, being awarded to or hosted by a more diverse array of countries including, for example, the FIFA
World Cup (e.g., South Africa, Brazil, Qatar, and Russia), which has arguably been led by the Olympic Movement with Summer Olympic Games (e.g., Tokyo, Moscow, Seoul, and Beijing), these tend to be the exception rather than the rule. In effect, there may be less frequent opportunities for researchers to study event volunteers in countries that host megaevents less frequently. Furthermore, many of the studies of events in the four dominant countries have collected data from some events on more than one occasion. For instance, samples were collected more than once in the men's World Cup of skiing in Whistler 1994, Honda Classics in 1997, Alliance London Jeux du Canada Games in 2001, Commonwealth Games (Manchester in 2002 and Melbourne in 2006), Twin Cities Marathon in 2004, Indianapolis Tennis Championship in 2005, USA National Special Olympics in 2006, Sony Ericsson Open in 2008, Turning Stone Resort Championship (PGA Tour event in 2009), Vancouver Olympics in 2010, British Women's Golf open in 2011, and the London Olympic Games in 2012. Third, main academic researchers in the US (19.7 \%), UK (17.1\%), Canada (15.9\%), and Australia (14.6\%) have published most articles on volunteer management in events compared to researchers from other countries. Furthermore, due to time and financial cost constraints, it is more likely that researchers study events that are located close to where they work rather than study events that are staged in other countries or regions.

\section{Rapid Increase in Volunteer Management in Events Research}

The field of event volunteer management has a research history of about 27 years with the first identified article published in 1988. After two decades of a comparatively slow but steady increase in research interest, as measured by published research articles, the field has accelerated rapidly since 2008. Conservatively assuming a doubling of research output in the next 7 years from 2015 in excess of 160 English language articles are likely to have been published on this topic by 2021. The rapid increase in event volunteer management research is indicative of the development of a critical mass of both research knowledge 
and researchers with an increasing level of expertise and specialist knowledge in this field. Further, the increase in research in this field is likely to be related to the growth of the event industry along with increased demand for volunteer labor. Improved volunteer management practices, in turn, are required in that well-managed volunteers are more likely to contribute to the success of an event. Such trends provide opportunities for the development of a more coordinated research agenda that encourages greater collaboration internationally between researchers, more frequent, open, and effective exchange of research ideas, and better use of limited resources for event volunteer research enabling more rapid and coherent development of the body of knowledge.

\section{Theoretical Base}

A limitation in the reviewed articles has been the lack of a clearly articulated theoretical basis. Fewer than $40 \%$ of the reviewed articles identified the theoretical underpinning and of those that articulated theory many articles cited rather than engaged with theory in a way that influenced either the research design or analysis. van Knippenberg (2011) noted, "Good theory explains. It captures causal relationships between concepts with a sufficient level of specificity to provide an explanation with enough detail to be insightful and to offer fertile ground for further theory development as well as practical application" (p. 4). Sutton and Staw (1995) also argued that "Strong theory delves into underlying processes so as to understand the systematic reasons for a particular occurrence or non-occurrence” (p. 378).

Interestingly, the most frequently applied theory within the reviewed articles was the theory of planned behavior, which has been used predominantly to explain and predict health related behaviors through behavioral intentions. The theory of planned behavior uses subjective norms, perceived behavioral control, and attitudes towards a specific behavior to predict behavioral intentions. There are substantial limitations to applying the theory of planned behavior to the behavior of event volunteers. The theory assumes a linear decision-making process, does not consider that behavioral intentions and behavior can change over time, and does not take into account the many external factors (e.g., HRM practices) that may influence the volunteer behavior in event settings. A lack of engagement with theory in all but one fifth of the reviewed research articles presents an opportunity for future research to actively participate in the development of theories that are relevant to furthering our understanding of volunteer management in events. Research informed by relevant various theories may be better able to predict and explain the effectiveness of HRM in managing event volunteers.

\section{Research Methods}

Decisions about research methods are influenced by several factors that include the scale of the study area, sample, type of event and access to the event, the purpose of the study, and the availability of data. Surveys were used as the chosen method in more than two thirds of the reviewed research articles, reflecting the dominance of a quantitative approach event volunteer management research. Survey methods might be the preferred approach for data collection because researchers focused mostly on sampling individual volunteers in more than four out of five of the reviewed research articles. There are proportionately few research articles that have used qualitative methods. According to Edwards and Skinner (2009), qualitative methods produce in-depth information and rich data. Aims and objectives of qualitative research are allowed to provide a detailed and interpreted understanding of social world of research participants by learning about the sense made of their social circumstances, their experiences, perspective, and histories (Ritchie, Lewis, Nicholls, \& Ormston, 2013). There are opportunities for future research to reflect different types of samples and research methods other than quantitative studies from the perspective of event volunteers.

\section{Volunteer Motivation}

The field of volunteer event management is dominated by studies of volunteer motivation as evidenced by the large proportion of studies that researched motivation as a key concept or construct. It is important for event managers and volunteer coordinators to better understand why volunteers engage in certain events and what influences their 
decision to continue to volunteer work at an event. Therefore, researchers are interested the correlates and causes of volunteer commitment, satisfaction, and retention, motivation is a good starting point. It is likely that the readily available volunteer motivation survey instruments such as the SEVMS, the VMS-ISE, and the OVMS encourage researchers to focus on the concept of motivation. However, measurement driven studies are sometimes light on theory and the high number of published volunteer motivation studies may go some way to explaining the lack of a theoretical basis for the majority of published peer-review research. Future event volunteer motivation research needs to engage with theory before considering which measurement instrument to use.

\section{Conclusions}

The literature on volunteer management in events has studied various aspects affecting the recruitment, commitment, and retention of volunteers. This article reviewed and found that the research on this topic is concentrated in certain countries, has increased rapidly over the last decade, tends to lack a clearly articulated theoretical basis, and reflects the dominance of a quantitative research design and focus on volunteer motivation. Because the research interest has accelerated rapidly, it may offer opportunities for the development of a more coordinated research effort between researchers across different countries. Evidence from this review suggests that there is a need for more theoretically informed event volunteer management research. Lack of a theoretical basis was most evident in many of the published volunteer motivation studies. Future event volunteer motivation research needs to apply theory before considering the application of a particular measurement instrument. Research derived from relevant theory will be needed to predict and adapt the effectiveness of HRM in managing event volunteers. Further, various types of samples and research methods other than quantitative studies are needed to provide a different and useful initial framework to examine various aims of research in the field of event volunteer management. This quantitative systematic review may provide an opportunity to develop a more strategic research agenda that encourages a more collaborative cross-national approach with the aim of better understanding volunteer management in events and more effective practical application of future research.

\section{References}

Ajzen, I. (1988). Attitudes, personality and behavior. Milton Keynes, UK: Open University Press.

Allen, J. B., \& Bartle, M. (2014). Sport event volunteers' engagement: Management matters. Managing Leisure, 19(1), 36-50.

Allen, J. B., O’Toole, W., Harris, R., \& McDonnell, I. (2005). Festival and special event management (3rd ed.). Milton, Australia: John Wiley \& Sons Australia.

Allen, J. B., \& Shaw, S. (2009). "Everyone rolls up their sleeves and mucks in”: Exploring volunteers' motivation and experiences of the motivational climate of a sporting event. Sport Management Review, 12(2), 79-90.

Alvesson, M., \& Willmott, H. (1992). Critical management studies. London: Sage.

Atkinson, J. (1984). Emerging UK work patterns. Brighton, UK: Institute for Manpower Studies.

Australian Sports Commission. (2000). Volunteer management program: Managing event volunteers. Canberra, Australia: Australian Sports Commission.

Bandura, A. (1991). Social cognitive theory of self-regulation. Organizational Behavior and Human Decision Processes, 50(2), 248-287.

Bang, H., Alexandris, K., \& Ross, S. D. (2008). Validation of the revised volunteer motivations scale for international sporting events (VMS-ISE) at the Athens 2004 Olympic Games. Event Management, 12(3-4), 119-131.

Bang, H., \& Ross, S. D. (2009). Volunteer motivation and satisfaction. Journal of Venue and Event Management, 1(1), 61-77.

Barron, P., \& Rihova, I. (2011). Motivation to volunteer: A case study of the Edinburgh International Magic Festival. International Journal of Event and Festival Management, 2(3), 202-217.

Beatty, R. W., Huselid, M. A., \& Schneier, C. E. (2003). New HR metrics: Scoring on the business scorecard. Organizational Dynamics, 32(2), 107-121.

Beck, U. (1992). Risk society: Toward a new modernity. London: Sage.

Becker, G. S. (1964). Human capital. New York: Columbia University Press.

Becker, G. S. (1976). The economic approach to human behavior. New York: University of Chicago Press.

Blau, P. (1964). Exchange and power in social life. New York: Wiley.

Bolman, L. G., \& Deal, T. E. (1991). Leadership and management effectiveness: A multi-frame, multi-sector analysis. Human Resource Management, 30(4), 509-534.

Bourdieu, P. (1977). Outline of a theory of practice. Cambridge, UK: Cambridge University Press.

Bourdieu, P. (1991). Language and symbolic power. Cambridge, UK: Polity Press. 
Bowdin, G. A. J., Allen, J., O’Toole, W., Harris, R., \& McDonnell, I. (2006). Events Management (2nd ed.). Oxford, UK: Elsevier Butterworth Heinemann.

Callero, P. L., Howard, J. A., \& Piliavin, J. A. (1987). Helping behavior as role behavior: Disclosing social structure and history in the analysis of prosocial action. Social Psychology Quarterly, 247-256.

Carlsen, J., \& Taylor, A. (2003). Mega-events and urban renewal: The case of the Manchester 2002 Commonwealth Games. Event Management, 8(1), 15-22.

Center for Civil Society Studies. (2014). Volunteer measurement project (VMP). Retrieved from http://ccss.jhu.edu/ research-projects/volunteer-measurement/

Clary, E., Snyder, M., Ridge, R. D., Copeland, J., Stukas, A. A., Haugen, J., \& Miene, M. (1998). Understanding and assessing the motivations of volunteers: A functional approach. Journal of Personality and Social Psychology, 74(6), 1516-1530.

Clary, E., Snyder, M., Ridge, R., Miene, P., \& Haugen, J. (1994). Matching messages to motives in persuasion: A functional approach to promoting volunteerism. Journal of Applied Social Psychology, 24(13), 1129-1149.

Coleman, J. S. (1988). Social capital in the creation of human capital. American Journal of Sociology, 94, 95-120.

Connors, T. D. (Ed.). (2011). The volunteer management handbook: Leadership strategies for success, Vol. 235. New York: John Wiley \& Sons.

Coyne, B. S., \& Coyne Sr., E. J. (2001). Getting, keeping and caring for unpaid volunteers for professional golf tournament events. Human Resource Development International, 4(2), 199-216.

Cuskelly, G., Hoye, R., \& Auld, J. (2006). Working with volunteers in sport: Theory and practice. New York: Routledge.

Cuskelly, G., Taylor, T., Hoye, R., \& Darcy, S. (2006). Volunteer management practices and volunteer retention: A human resource management approach. Sport Management Review, 9(2), 141-163.

Dawis, R. V., \& Lofquist, L. H. (1984). A psychological theory of work adjustment: An individual-differences model and its applications. Minneapolis, MN: University of Minnesota Press.

Deb, T. (2009). Managing human resource and industrial relations. New Delhi, India: Excel Books India.

Dickson, T. J., Benson, A. M., Blackman, D. A., \& Terwiel, F. A. (2013). It's all about the games! 2010 Vancouver Olympic and Paralympic winter games volunteers. Event Management, 17(1), 77-92.

Dickson, T. J., Benson, A. M., \& Terwiel, F. A. (2014). Mega-event volunteers, similar or different? Vancouver 2010 vs. London 2012. International Journal of Event and Festival Management, 5(2), 164-179.

Downward, P., \& Ralston, R. (2005). Volunteer motivation and expectations prior to the XV Commonwealth Games in Manchester, UK. Tourism and Hospitality Planning \& Development, 2(1), 17-26.

Edwards, A., \& Skinner, J. (2009). Qualitative research in sport management. Oxford, UK: ButterworthHeinemann.
Elstad, B. (2003). Continuance commitment and reasons to quit: A study of volunteers at a jazz festival. Event Management, 8(2), 99-108.

Fairley, S., Kellett, P., \& Green, B. C. (2007). Volunteering abroad: Motives for travel to volunteer at the Athens Olympic Games. Journal of Sport Management, 21(1), 41-57.

Farrell, J. M., Johnston, M. E., \& Twynam, G. D. (1998). Volunteer motivation, satisfaction, and management at an elite sporting competition. Journal of Sport Management, 12(4), 288-300.

Federation Internationale de Football Association. (2012). Brazil 2014 volunteer programme explained. Retrieved from http://www.fifa.com/worldcup/news/newsid=1552 $732 /$

Fishbein, M., \& Ajzen, I. (1975). Belief, attitude, intention and behavior: An introduction to theory and research. Reading, MA: Addison-Wesley.

Getz, D. (1991). Festivals, special events, and tourism. New York: Van Nostrand Reinhold.

Getz, D. (2005) Event management and event tourism (2nd ed.). New York: Cognizant Communication.

Getz, D. (2008). Event tourism: Definition, evolution, and research. Tourism Management, 29(3), 403-428.

Getz, D., \& Frisby, W. (1988). Evaluating management effectiveness in community-run festivals. Journal of Travel Research, 27(1), 22-27.

Giannoulakis, C., Wang, C. H., \& Gray, D. (2007). Measuring volunteer motivation in mega-sporting events. Event Management, 11(4), 191-200.

Grey, C., \& Willmott, H. (2005). Critical management studies: A reader. Oxford, UK: Oxford University Press.

Hallmann, K., \& Harms, G. (2012). Determinants of volunteer motivation and their impact on future voluntary engagement: A comparison of volunteer's motivation at sport events in equestrian and handball. International Journal of Event and Festival Management, 3(3), 272-291.

Han, K., Quarterman, J., Strigas, E., \& Ha, J. (2013). Committed sport event volunteers. ICHPER-SD Journal of Research in Health, Physical Education, Recreation, Sport \& Dance, 8(2), 45-54.

Herzberg, F. (1986). One more time: How do you motivate employees. New York: The Leader Manager, 433-448.

Holmes, K., \& Smith, K. (2009). Managing volunteers in tourism: Attractions, destinations and events. Oxford, UK: Butterworth-Heinemann.

Homans, G. C. (1958). Social behavior as exchange. American Journal of Sociology, 597-606.

Houle, B., Sagarin, B., \& Kaplan, M. (2005). A functional approach to volunteerism: Do volunteer motives predict task preference? Basic and Applied Social Psychology, 27(4), 337-344.

International Labour Organization. (2011). Manual on the measurement of volunteer work. Switzerland: ILO Geneva. Retrieved from http://www.ilo.org/wcmsp5/ groups/public/---dgreports/---dcomm/---publ/documents/ publication/wcms_167639.pdf 
Katz, D. (1960). The functional approach to the study of attitudes. Public Opinion Quarterly, 24, 163-204.

Keenoy, T. (1999). HRM as hologram: A polemic. Journal of Management Studies, 36(1), 1-23.

Kemp, S. (2002). The hidden workforce: Volunteers' learning in the Olympics. Journal of European Industrial Training, 26(2/3/4), 109-116.

Khoo, S., \& Engelhorn, R. (2011). Volunteer motivations at a national Special Olympics event. Adapted Physical Activity Quarterly, 28(1), 27-39.

Lavarie, D. A., \& Arnett, D. B. (2000). Factors affecting fan attendance: The influence of identity salience and satisfaction. Journal of Leisure Research, 32(2), 225-246.

Macduff, N. (1999). Episodic volunteering. In T.D. Connors (Ed.), The volunteer management handbook (pp. 187205). New York: John Wiley \& Sons.

MacLean, J., \& Hamm, S. (2007). Motivation, commitment, and intentions of volunteers at a large Canadian sporting event. Leisure/Loisir, 31(2), 523-556.

Maslow, A. (1987). Motivation and personality. New York: Harper \& Row.

Neuman, W. L. (2011). Social research methods: Qualitative and quantitative approaches (7th ed.). Boston, MA: Pearson.

Nichols, G., \& Ojala, E. (2009). Understanding the management of sports events volunteers through psychological contract theory. VOLUNTAS: International Journal of Voluntary and Nonprofit Organizations, 20(4), 369-387.

Pauline, G., \& Pauline, J. S. (2009). Volunteer motivation and demographic influences at a professional tennis event. Team Performance Management, 15(3/4), 172-184.

Peterson, D. (2004). Recruitment strategies for encouraging participation in corporate volunteer programs. Journal of Business Ethics, 49(4), 371-386.

Petticrew, M. (2001). Systematic reviews from Astronomy to Zoology: Myths and misconceptions. British Medical Journal, 322(7278), 98-101.

Pickering, C., \& Byrne, J. (2014). The benefits of publishing systematic quantitative literature reviews for $\mathrm{PhD}$ candidates and other early-career researchers. Higher Education Research \& Development, 33(3), 534-548.

Pickering, C., Grignon, J., Steven, R., Guitart, D., \& Byrne, J. (2014). Publishing not perishing: How research students transition from novice to knowledgeable using systematic quantitative literature reviews. Studies in Higher Education, 1-14.

Portes, A. (1998). Social capital: Its origins and applications in modern sociology. Annual Review of Sociology, 24, $1-24$.

Ritchie, J. B. (1984). Assessing the impact of hallmark events: Conceptual and research issues. Journal of Travel Research, 23(1), 2-11.

Ritchie, J., Lewis, J., Nicholls, C. M., \& Ormston, R. (Eds.). (2013). Qualitative research practice: A guide for social science students and researchers. London: Sage.

Roche, M. (1994). Mega-events and urban policy. Annals of Tourism Research, 21, 1-19.
Roche, M. (2000). Mega-events: Olympics and expos in the growth of global culture. London: Routledge.

Rolfe, H. (1992). Arts festivals in the UK. London: Policy Studies Institute.

Rousseau, D. M. (1989). Psychological and implied contracts in organizations. Employee Responsibilities and Rights Journal, 8, 121-139.

Roy, S., Pickering, C., \& Byrne, J. (2012). A systematic quantitative review of urban tree benefits, costs, and assessment methods across cities in different climatic zones. Urban Forestry and Urban Greening, 11, $351-363$.

Ryan, C., \& Bates, C. (1995). A rose by any other name: The motivations of those opening their gardens for a festival. Festival Management \& Event Tourism, 3(2), 59-71.

Ryan, R. M., \& Deci, E. L. (2000). Self-determination theory and the facilitation of intrinsic motivation, social development, and well-being. American Psychologist, 55(1), 68-78.

Safrit, R. D., Schmiesing, R. J., Gliem, J. A., \& Gliem, R. R. (2005). Core competencies for volunteer administration: An empirical model bridging theory with professional best practice. Journal of Volunteer Administration, 23(3), 5-15.

Shank, M. D., \& Beasley, F. M. (1998). Fan or fanatic: Refining a measure of sports involvement. Journal of Sport Behavior, 21(4), 435-443.

Skille, E. Å., \& Hanstad, D. V. (2013). Who are they and why do they do it? The habitus of sport event volunteers in Norway: Volunteers at the European handball championship for women 2010. Sport in Society, 16(9), 1135-1148.

Skirstad, B., \& Hanstad, D. V. (2013). Gender matters in sport event volunteering. Managing Leisure, 18(4), 316-330.

Sutton, R. I., \& Staw, B. M. (1995). What theory is not. Administrative Science Quarterly, 371-384.

Thibault, J. W., \& Kelly, H. H. (1959). The social psychology of groups. New York: Wiley.

Todd, S. Y., Crook, T. R., \& Barilla, A. G. (2005). Hierarchical linear modeling of multilevel data. Journal of Sport Management, 19(4), 387-403.

Twynam, G. D., Farrell, J. M., \& Johnston, M. E. (2002). Leisure and volunteer motivation at a special sporting event. Leisure/Loisir, 27(3-4), 363-377.

van Knippenberg, D. (2011). Advancing theory in organizational psychology. Organizational Psychology Review, 1(1), 3-8.

Wang, C., \& Wu, X. (2014). Volunteers' motivation, satisfaction, and management in large-scale events: An empirical test from the 2010 Shanghai World Expo. VOLUNTAS: International Journal of Voluntary and Nonprofit Organizations, 25(3), 754-771.

Wann, D. L., Melnick, M. J., Russell, G. W., \& Pease, D. G. (2001). Sport fans-The psychology and social impacts of spectators. New York \& London: Routledge.

Wicker, P., \& Hallmann, K. (2013). A multi-level framework for investigating the engagement of sport 
volunteers. European Sport Management Quarterly, 13(1), 110-139.

Williams, P. W., Dossa, K. B., \& Tompkins, L. (1995). Volunteerism and special event management: A case study of Whistler's Men's World Cup of Skiing. Festival Management and Event Tourism, 3(2), 83-95.
Wollebæk, D., Skirstad, B., \& Hanstad, D. V. (2014). Between two volunteer cultures: Social composition and motivation among volunteers at the 2010 test event for the FIS Nordic World Ski Championships. International Review for the Sociology of Sport, 49(1), 22-41. 